\title{
Evaluation of six different DNA extraction methods for detection of Mycobacterium tuberculosis by means of PCR-IS6110: preliminary study
}

\author{
Isabela Neves de Almeida', Wânia da Silva Carvalho', Maria Lúcia Rossetti², Elis Regina Dalla Costa² \\ and Silvana Spindola de Miranda ${ }^{3^{*}}$
}

\begin{abstract}
Background: Developments in molecular detection and strain differentiation of members of Mycobacterium tuberculosis complex have proved to be useful. The DNA extraction method influences the amplification efficiency, causing interference on the sensitivity and respective inhibitors. The aim of this study was to standardize a simple and fast DNA extraction method, providing DNA amplification by IS6110-PCR effectively free from undue interferences.

Findings: The efficiency of the six different protocols tested in M. tuberculosis cultures has varied from $75 \%$ to $92.5 \%$. This preliminary study evaluating the IS6110 PCR sensitivity and specificity was developed in DNA extracted from microscope slides, and achieved 100\% of efficiency.

Conclusions: DNA extraction by Chelex + NP-40 method from both, cultures of M. tuberculosis and smear slides, resulted in good quantity of interference free DNA, especially in samples with low concentrations of genetic material; therefore, such technique may be used for the molecular diagnosis of tuberculosis.
\end{abstract}

Keywords: M. tuberculosis, IS6110, DNA extraction, PCR

\section{Background}

Tuberculosis (TB) is one of the leading chronic bacterial infections, with mortality of almost 3 million and more than 8 million new cases every year [1]. Early diagnosis, effective treatment, and successful termination of transmission are major strategies for TB control [2].

Polymerase Chain Reaction (PCR) is a fast and sensitive diagnostic method for detection and identification of $M$. tuberculosis, especially in samples with poor load of bacilli [3]; and the most used molecular marker for DNA amplification is the IS6110 insertion element; which is specific for the genome of M. tuberculosis complex species [4].

Some studies report different sensitivity and specificity results, when using PCR techniques as diagnostic

\footnotetext{
* Correspondence: silvanaspindola@gmail.com

${ }^{3}$ Research Group Coordinator FM/UFMG_REDE-TB, Belo Horizonte, Minas Gerais, Brazil

Full list of author information is available at the end of the article
}

investigation tool; such results vary from 11 to $81 \%$ [5]. There are many reasons for this frequent variability of PCR results; however, earlier studies have suggested that PCR outcomes largely depend on the DNA extraction method [6].

DNA extraction methods should be effective, simple, and rapid, eliminating also the presence of PCR inhibitors during extraction [6,7].

Thus, the aim of this study was to standardize a simple, fast, and less complex method of DNA extraction, providing also DNA amplification by IS6110-PCR free from any undue interference.

\section{Methods}

\section{Clinical data}

The samples included in this study came from patients assisted in the Hospital of Clinics of the Federal University of Minas Gerais (UFMG), in the years of 2010 and 2011. Patients care comprised only individuals older

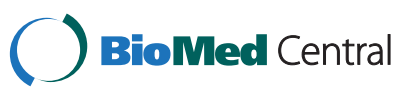


than 18 years, who are presenting TB suspicion and have not started the treatment yet, as demonstrated in Tables 1 and 2. All patients that received TB diagnosis treated with anti-TB drugs.

\section{Samples}

Ten bacterial dilutions of $M$. tuberculosis in LöwensteinJensen culture medium have been tested, using serial dilutions of 1/10,1/100 and 1/1000; a total of 230 dilutions were tested with different DNA extraction methods.

Two bacterial suspensions of $\mathrm{H} 37 \mathrm{Rv}$ strain of $M$. tuberculosis were used as positive control.

Five slides with positive bacilloscopy sputum (one + and two ++ ) and one with negative bacilloscopy were selected, coming from the Mycobacterial Laboratory of the Hospital of Clinics, at the Federal University of Minas Gerais. The slides were stained by fluorescence method (Auramine O), to be submitted to extraction procedure.

\section{Samples preparation}

\section{M. tuberculosis inactivation}

For DNA extraction from culture, a bacterial suspension containing $1.5 \mathrm{~mL}$ of sterile water and around 3 to $5 \mathrm{col}-$ onies of H37Rv strain of M. tuberculosis was prepared in Eppendorf tubes. This suspension was inactivated at $100^{\circ} \mathrm{C}$ for 30 minutes in thermo block, and then centrifuged at $14,000 \mathrm{rpm}$ for 10 minutes, at $4^{\circ} \mathrm{C}$. The supernatant was discarded, and the sediment was used in Extraction Protocols 1, 2, 3, 4, and 5. For Extraction Protocol 6, the initial stage was different and will be described further.

\section{Preparation and staining of smears slides}

The smears were done before the samples' decontamination step with $0.5 \% \mathrm{~N}$-acetyl-L-cysteine $/ 2 \% \mathrm{NaOH}$ (NaLC/NaOH) [8]. M. tuberculosis and Non-tuberculous Mycobacteria (NTM) species were confirmed after growth in Löwenstein-Jensen culture medium, and identified by

Table 1 Clinical data from patients included in the protocols of extraction from cultures

\begin{tabular}{llllll}
\hline Patients & Gender & Origin & Hypothesis/Symptoms & Past TB & HIV \\
\hline 3 & m & Ward & Cough to clarify & No & Yes \\
4 & $m$ & Outpatient & TB & No & No \\
5 & m & Ward & Fever to clarify & No & No \\
6 & f & Ward & TB & No & No \\
7 & $m$ & EU & TB & No & No \\
8 & m & Ward & TB & Yes & Yes \\
9 & $f$ & Ward & TB & No & No \\
10 & $m$ & Ward & TB & No & No \\
\hline
\end{tabular}

$\mathrm{m}=$ male; $\mathrm{f}=$ female; $\mathrm{EU}=$ emergency unit; $\mathrm{TB}=$ tuberculosis; HIV = Human Immunodeficiency Virus. basic biochemical methods, in the Ezequiel Dias Foundation Reference Center [9].

\section{Extraction}

\section{M. tuberculosis culture DNA extraction}

Extraction protocol 1 - extraction using phenol-chloroform DNA from $M$. tuberculosis strains was prepared as follows, after neutralization: a pellet of $400 \mu \mathrm{L}$ of lysozyme solution $(10 \mathrm{mg} / \mathrm{mL}$ ) was added to the suspension, and incubated for 1 hour at $37^{\circ} \mathrm{C}$. Afterwards, $20 \mu \mathrm{L}$ EDTA $(50 \mathrm{mM})+$ $400 \mu \mathrm{L}$ of proteinase $\mathrm{K}$ solution $(10 \mathrm{mg} / \mathrm{mL})$ were added, and the mixture was incubated at $60^{\circ} \mathrm{C}$ for 1 hour. Then, the solution was stored at $-20^{\circ} \mathrm{C}$ overnight, and the DNA was extracted with phenol-chloroform and ethanol. After freezing, the solution was divided into two parts, and $400 \mu \mathrm{L}$ of phenol-chloroform were added in each vortex tube and centrifuged at $12,000 \mathrm{rpm}$ for 15 minutes. The supernatant was then transferred to another tube, and 0.6 volume of isopropanol and 1/10 volume of sodium acetate were added; homogenizing then the solution until white color disappearance. The solution was then stored again at $-20^{\circ} \mathrm{C}$, for 30 minutes. After that, it was centrifuged at $12,000 \mathrm{rpm}$ for 10 minutes, and the supernatant was discarded. The pellet was washed twice with $500 \mu \mathrm{L}$ of $70 \%$ ethanol, and after complete evaporation $20 \mu \mathrm{L}$ of TE (Tris $100 \mu \mathrm{M}+$ EDTA $50 \mu \mathrm{M}$ ) were added to it. The DNA was conserved at $2-8^{\circ} \mathrm{C}$, until PCR development. This method was considered the standard method [10].

\section{Extraction protocol 2 - extraction using $70 \%$ alcohol}

$500 \mu \mathrm{L}$ of $70 \%$ Ethanol were added to a pellet in a tube, and incubated for 2 hours. Then, mycobacterial cells were centrifuged at $13,000 \mathrm{rpm}$ for 10 minutes, the supernatant was discarded, and the pellet was washed twice with sterile distilled water. After washing, the pellet was resuspended in $500 \mu \mathrm{L}$ of sterile distilled water within an Eppendorf tube of $1.5 \mathrm{~mL}$, being then used for PCR [11].

\section{Extraction protocol 3 - extraction using Chelex $100+$ Nonidet $P$-40 (NP-40)}

$200 \mu \mathrm{l}$ of solution were added to a pellet from Chelex suspension containing 5\% Chelex-100, 1\% Nonidet P-40, $1 \%$ Tween 20, and distilled water. After mixing thoroughly, the samples were maintained for 30 minutes at $100^{\circ} \mathrm{C}$. The samples were then centrifuged for $10 \mathrm{mi}-$ nutes at $13,000 \mathrm{~g}$, and the solution was transferred to a fresh microcentrifuge tube and used for PCR [8].

\section{Extraction protocol 4 - extraction using Chelex 100}

$200 \mu \mathrm{L}$ of a solution containing $40 \mathrm{mg}$ Chelex $100+$ $100 \mathrm{~mL}$ of water were added to a pellet, and the resulting material was maintained at $95^{\circ} \mathrm{C}$ for 20 minutes. Then, it 
Table 2 Clinical data of patients included in protocols of extraction from microscope slides

\begin{tabular}{llllll}
\hline Patients & Gender & Origin & Hypothesis/Symptoms & Past TB & HIV \\
\hline 1 & $\mathrm{~m}$ & Ward & Fever to clarify & No & Nos \\
2 & $\mathrm{f}$ & Outpatient & Cough to clarify & No & Yes \\
3 & $\mathrm{~m}$ & Outpatient & TB & Yes & No \\
4 & $\mathrm{f}$ & Outpatient & Cough and emaciation to clarify & No \\
5 & $\mathrm{f}$ & Outpatient & TB or nocardiosis & Yes \\
\hline
\end{tabular}

$\mathrm{m}=$ male; $\mathrm{f}=$ female; $\mathrm{TB}=$ tuberculose tuberculosis; HIV = Human Immunodeficiency Virus.

was centrifuged at $12,000 \mathrm{~g}$ for 15 minutes. The supernatant was used as a DNA source for PCR [12].

\section{Extraction protocol 5 - extraction using Chelex $100+70 \%$ Alcohol}

A total of $150 \mu \mathrm{L}$ of ice-cold $70 \%$ ethanol was added to a tube, mixed thoroughly, and maintained in ice $\left(-20^{\circ} \mathrm{C}\right)$ for 20 minutes. The suspension was then centrifuged at $12,000 \mathrm{rpm}$ for 5 minutes, and $200 \mu \mathrm{l}$ of $20 \%$ Chelex solution were added to the pellet. The mixture was then vigorously stirred with a shaker, and incubated at $55^{\circ} \mathrm{C}$ for 1 hour. It was then placed in the vortex again, at high speed, for $10-20$ seconds. The tubes were maintained at $100^{\circ} \mathrm{C}$ for 15 minutes. Then, the tubes were centrifuged at $12,000 \mathrm{rpm}$ for 5 minutes, at $4^{\circ} \mathrm{C}$. Afterwards, the supernatant was transferred to a new tube and used for PCR [6].

\section{Extraction protocol 6 - extraction using chloroform + CTAB(N-cetyl-N,N,Ntrimethyl ammonium bromide)}

Several bacteria loopfuls were resuspended in $400 \mu \mathrm{L}$ of TE $1 \mathrm{X}$ buffer, and then inactivated at $80^{\circ} \mathrm{C}$ for $20 \mathrm{mi}$ nutes. $50 \mu \mathrm{L}$ of lysozyme solution were added to the vortex and incubated at $37^{\circ} \mathrm{C}$ for at least 1 hour, under stirring. $70 \mu \mathrm{L}$ of SDS $10 \%$ and $5 \mu \mathrm{L}$ of proteinase $\mathrm{K}$ were added to the vortex, and incubated at $65^{\circ} \mathrm{C}$ for 10 minutes. $100 \mu \mathrm{L}$ of $\mathrm{NaCl} 5 \mathrm{M}$ and $100 \mu \mathrm{L}$ of $\mathrm{CTAB} / \mathrm{NaCl}$ solution were added to the vortex until the liquid content becoming white; then, it was incubated for $10 \mathrm{mi}$ nutes at $65^{\circ} \mathrm{C}$. $750 \mu \mathrm{L}$ of chloroform/isoamyl alcohol (24:1) were added to the vortex for 10 seconds, and centrifuged at room temperature for 5 minutes, at 14,000 g. The supernatant was transferred to a clean tube and 0.6 volume of isopropanol was added. It was incubated at $-20^{\circ} \mathrm{C}$ for 30 minutes, and centrifuged for 15 minutes at $14,000 \mathrm{~g}$. The supernatant was discarded and the pellet washed with $1 \mathrm{~mL}$ of $70 \%$ ethanol and centrifuged for 5 minutes at $14,000 \mathrm{~g}$. To precipitate the DNA, 20$30 \mu \mathrm{L}$ of TE were added [13].

\section{M. tuberculosis DNA extraction from smear slides of sputum Chelex $100+$ Nonidet P-40 (NP-40) on slides}

The sputum smears on slides were submitted to Chelex $100+$ Nonidet P-40 (NP-40) extraction, as it was the most effective method among the six tested ones.
A volume of $25 \mu \mathrm{L}$ of a suspension containing $5 \%$ Chelex-100, 1\% Nonidet P-40, 1\% Tween 20, and distilled water was spread on the smear slides with a pipette tip. The liquid was transferred to an Eppendorf tube and $75 \mu \mathrm{L}$ of the same suspension were added. After mixing thoroughly, the samples were incubated for 30 minutes at $100^{\circ} \mathrm{C}$. The samples were then centrifuged for 10 minutes at $13,000 \mathrm{~g}$, and the solution was transferred to a fresh microcentrifuge tube; then, $5 \mu \mathrm{L}$ were used for PCR [8].

\section{PCR and electrophoresis}

PCR was performed in a final volume of $50 \mu \mathrm{L}$ containing $7.0 \mu \mathrm{L}$ of Buffer (10x), $3.0 \mu \mathrm{L}$ of $\mathrm{MgCl}_{2}(50 \mathrm{mM})$, $0.2 \mu \mathrm{L}$ of DNTP (25 mM), $25 \mathrm{pmol}$ of each oligonucleotide (IS1- 5' CCT GCG AGC GTA GGC GTC GG 3' and IS2- 5' CTC GTC CAG CGC CGC TTC GG 3') and $0.5 \mu \mathrm{L}$ of Taq DNA Polymerase (500 U) Invitrogen ${ }^{\bullet}$. Amplification was carried out for 40 cycles, each consisting of initial denaturation at $94^{\circ} \mathrm{C}$ for $2 \mathrm{~min}$, denaturation at $94^{\circ} \mathrm{C}$ for 30 seconds, annealing at $64^{\circ} \mathrm{C}$ for 2 minutes, extension at $71^{\circ} \mathrm{C}$ for 1 minute, followed by a final extension at $72^{\circ} \mathrm{C}$ for 10 minutes. PCR products were analyzed by gel electrophoresis in $2 \%$ agarose gel. Target DNA fragments of one hundred twenty-three base pairs (bp) were viewed under UV light.

\section{Quantitative assessment of extracted DNA}

The DNA dosing was executed by spectrophotometry (SpectraMax Plus ${ }^{\oplus}$ ). The absorbance and DNA concentration (ideal 5-100 $\mathrm{ng} / \mu \mathrm{L}$ ) were evaluated as indicative of nucleic acids purity (ideal ratios: $A_{260} / A_{280} \geq 1.8$ and $\left.\mathrm{A}_{260} / \mathrm{A}_{230}=2\right)[14,15]$.

A volume of $5 \mu \mathrm{L}$ of concentrated DNA, and the respective dilutions $(1 / 10,1 / 100$, and $1 / 1000)$, were submitted to PCR reaction, and dosed in the spectrophotometer SpectraMax Plus ${ }^{\circledast}$ (using $2 \mu \mathrm{L}$ as per manufacturer's instruction).

\section{Findings}

M. tuberculosis DNA dosing exhibited concentrations ranging from $1.048 \mathrm{ng} / \mu \mathrm{L} ; 4.33 \mathrm{ng} / \mu \mathrm{L} ; 47.78 \mathrm{ng} / \mu \mathrm{L}$; $182.5 \mathrm{ng} / \mu \mathrm{L} ; 112.3 \mathrm{ng} / \mu \mathrm{L} ; 7.0 \mathrm{ng} / \mu \mathrm{L}$ in protocols $1,2,3$, 4,5 , and 6 , respectively (Figure 1 ).

The average value of $A_{260} / A_{280}$ and $A_{260} / A_{230}$ ratios is demonstrated in Table 3. 


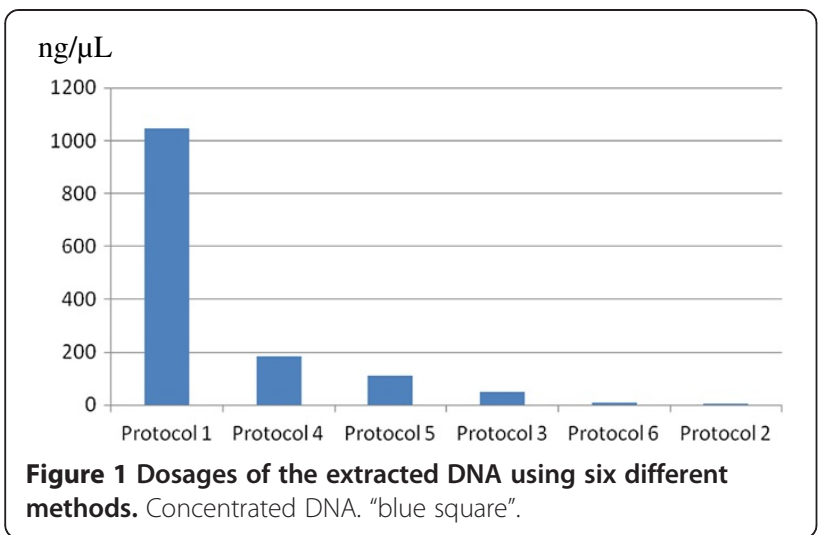

The efficiency of Extraction Protocols 1, 2, 3, 4, 5 and 6, developed in M. tuberculosis.

Cultures was respectively of: $75 \%(30 / 40), 75 \%(30 / 40)$, 90\% (36/40), 75\% (30/40) 77.5\% (31/40), and 92.5\% (37/40).

The methods presenting better performance were Extraction Protocols 3 and 6 (90\% and 92.5\%); however, protocol 3 did not show negative results even in dilution 1/1000.

The amplification results after DNA extraction from ten $M$. tuberculosis cultures are shown in Table 4.

Figure 2 shows electrophoresis of amplifications performed with Extraction Protocol 3.

There was amplification in 4 slides with $M$. tuberculosis positive cultures, and the slide with $M$. kansasii culture was not amplified by IS6110-PCR. The DNA extracted from the smear slides using Extraction Protocol 3 are shown in Table 5. Electrophoresis from smear slides amplification is shown in Figure 3.

\section{Discussion}

DNA dosing from cultures after extraction is an important parameter to quantify the extracted amount and evaluate its quality (purity); however, as evidenced in our results, it is not an absolute parameter $[16,17]$, as large variation was verified either in 'DNA concentration' or 'absorbance' values, with no relationship with PCR-IS6110 amplification.

This study demonstrated the application of several DNA extraction methods, and found an inter-methods efficiency variation of $75 \%$ to $92.5 \%$ of PCR-IS6110,

Table 3 Average absorbance with extraction protocols

\begin{tabular}{lcc}
\hline & $\begin{array}{c}\mathbf{A}_{\mathbf{2 6 0}} / \mathbf{A}_{\mathbf{2 8 0}} \\
(\geq \mathbf{1 . 8})\end{array}$ & $\begin{array}{c}\mathbf{A}_{\mathbf{2 6 0}} / \mathbf{A}_{\mathbf{2 3 0}} \\
(<\mathbf{2 . 0})\end{array}$ \\
\hline Protocol 1 & 1.96 & 1.69 \\
Protocol 2 & 1.24 & -0.74 \\
Protocol 3 & 1.28 & 0.62 \\
Protocol 4 & 0.46 & 0.13 \\
Protocol 5 & 1.26 & 0.46 \\
Protocol 6 & -1.13 & 0.21 \\
\hline
\end{tabular}

Table 4 Amplification after extraction of ten M. tuberculosis cultures

\begin{tabular}{|c|c|c|c|c|c|c|c|c|c|c|c|}
\hline & & \multicolumn{10}{|c|}{ DNA of tuberculosis cultures } \\
\hline & & $1(\mathrm{PC})$ & 2 & 3 & 4 & 5 & 6 & 7 & 8 & 9 & 10 \\
\hline Protocol & Concentrated & + & + & + & - & + & + & + & + & + & + \\
\hline \multirow[t]{3}{*}{1} & Dilution 1:10 & + & + & + & - & + & + & + & - & + & + \\
\hline & Dilution 1:100 & - & + & + & - & + & + & + & + & + & - \\
\hline & Dilution 1:1000 & - & + & - & + & + & + & - & + & + & - \\
\hline Protocol & Concentrated & + & + & + & - & + & + & + & + & + & + \\
\hline \multirow[t]{3}{*}{2} & Dilution 1:10 & + & - & + & - & + & + & + & + & - & + \\
\hline & Dilution1:100 & + & - & + & + & + & + & + & + & - & + \\
\hline & Dilution 1:1000 & + & - & + & + & + & + & - & + & - & - \\
\hline Protocol & Concentrated & + & + & + & + & + & + & + & + & - & + \\
\hline \multirow[t]{3}{*}{3} & Dilution 1:10 & + & + & + & + & + & + & + & + & + & + \\
\hline & Dilution 1:100 & + & + & + & - & + & + & + & + & - & + \\
\hline & Dilution 1:1000 & + & + & + & - & + & + & + & + & + & + \\
\hline otocol & Concentrated & + & + & + & + & + & + & + & + & - & + \\
\hline & Dilution 1:10 & + & + & + & - & + & + & + & + & - & + \\
\hline & Dilution 1:100 & + & + & + & - & - & + & + & + & - & + \\
\hline & Dilution 1:1000 & + & - & + & - & - & + & + & - & + & + \\
\hline Protocol & Concentrated & + & + & + & + & + & + & + & + & + & + \\
\hline & Dilution 1:10 & + & + & + & + & + & + & + & + & + & + \\
\hline & Dilution 1:100 & + & + & + & - & + & + & + & + & - & + \\
\hline & Dilution 1:1000 & + & - & - & - & + & + & - & - & - & - \\
\hline Protocol & Concentrated & + & + & + & - & + & + & + & + & + & + \\
\hline & Dilution 1:10 & + & + & + & + & + & + & + & + & + & + \\
\hline & Dilution 1:100 & + & + & + & + & + & + & + & + & + & + \\
\hline & Dilution 1:1000 & + & + & + & - & - & + & - & + & + & + \\
\hline
\end{tabular}

PC: positive control; + positive; - negative.

which proves that the extraction method does not exert direct influence on the IS6110-PCR effectiveness.

The number of steps and reagents, and the nature of chemical reagents (proteolytic enzymes, organic solvents, alcohols, and resins) used show the difference between the six extraction methods. Extraction Protocols 1 and 6 (Phenol-chloroform and Chloroform + CTAB) used lysozyme and proteinase $\mathrm{K}$ in the first extraction phase, which led to cellular membranes rupture and release of cytoplasmic components, due to digestion by proteolytic enzymes. Organic solvents as phenol and chloroform were also used, separating DNA from lipids and other biochemical compounds; the addition of ethanol occurred as well, to recover and purify the DNA. The use of CTAB allowed to improve the sensitivity, as it has better action on DNA purification [14].

Extraction Protocols 2 and 5 (70\% Alcohol and Chelex $100+70 \%$ Alcohol) used 70\% alcohol aiming DNA purification. 70\% alcohol helps in the removal of organic waste that could act as PCR inhibitors [10]. Within these 


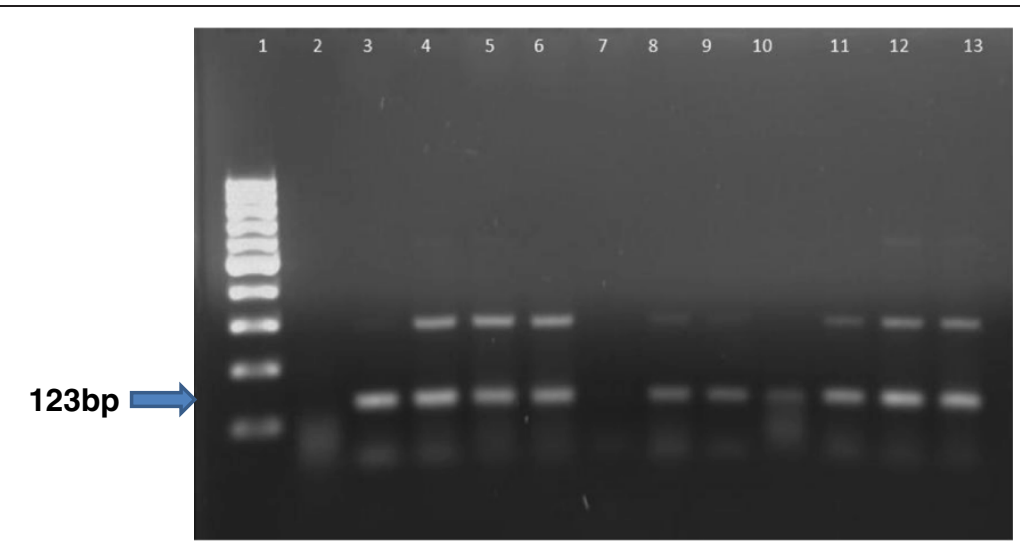

Figure 2 Agarose gel electrophoresis of amplifications performed with protocol 3. Lane $1=$ Molecular marker 100 bp, Lane $2=$ Negative Control, Lane 3 = Positive Control, Lane 4 =Sample 8, Lane 5 =Sample 6, Lane 6 = Sample 7, Lane 7 =Sample9, Lane 8=Sample 5, Lane 9=Sample 10, Lane $10=$ Sample 4, Lane $11=$ Sample 3, Lane 12 = Sample 1, Lane $13=$ Sample 2.

two protocols, elimination of large amounts of organic waste in the concentrated samples is evidenced through the action of $70 \%$ alcohol, which is best shown in Extraction Protocol 5, as all concentrated cultures were amplified, and resin (Chelex 100) was used to help the DNA removal from cell inside [6].

Extraction Protocols 3 and 4. (Chelex $+N P-40$ and Chelex 100) used Chelex 100 resin as principal reagent for DNA extraction, which is associated to thermal shock and NP-40 in order to purify the DNA. These extraction protocols are fast; however, Extraction Protocol 3, which uses NP-40, had a higher efficiency when DNA was amplified (90\%), demonstrating its possible use for saving time as compared to Extraction Protocol 1 (Phenol Chloroform), which has been described by some authors as the gold standard for DNA extraction [18].

Extraction Protocol 3 presented the best culture results in extraction; so, using this protocol in smear slides enables the recovery of smaller amounts (dilution 1/1000) of M. tuberculosis DNA, consuming less reagents, with less stages, and without inhibitors; so, this method is effective, practical, and fast.

In this work, we have noticed that a simpler protocol (Extraction Protocol 3), presenting fewer stages and

Table 5 Results of amplifications after extraction of DNA from five smears in sputum slides

\begin{tabular}{llll}
\hline & AFB AU & PCR & Culture \\
\hline Sample 1 & ++ & pos & M. tuberculosis \\
Sample 2 & + & pos & M. tuberculosis \\
Sample 3 & - & pos & M. tuberculosis \\
Sample 4 & ++ & pos & M. tuberculosis \\
Sample 5 & + & neg & M. kansasii \\
\hline
\end{tabular}

+ and ++ positives; pos = positive; neg = negative; $\mathrm{PCR}=$ Polymerase Chain Reaction; AFB AU = Acid-fast bacilli by Auramine. consuming less reagents, presented results similar to those from more complex protocols (Extraction Protocol 6), presenting also higher efficiency with lower DNA concentrations (1/1000). Protocol 3 has been employed by some authors, since it does not use any organic solvent, eliminates multiple stages of purification, and uses only two Eppendorf tubes per sample, decreasing so the costs and time spent [7].

The authors used Extraction Protocol 3 (Chelex + NP-40) for DNA extraction in smear slides, due to its higher efficiency between protocols tested in culture. The good PCR performance exhibited in samples extracted by Chelex + $N P-40$ may be associated to the fact that NP-40 is a

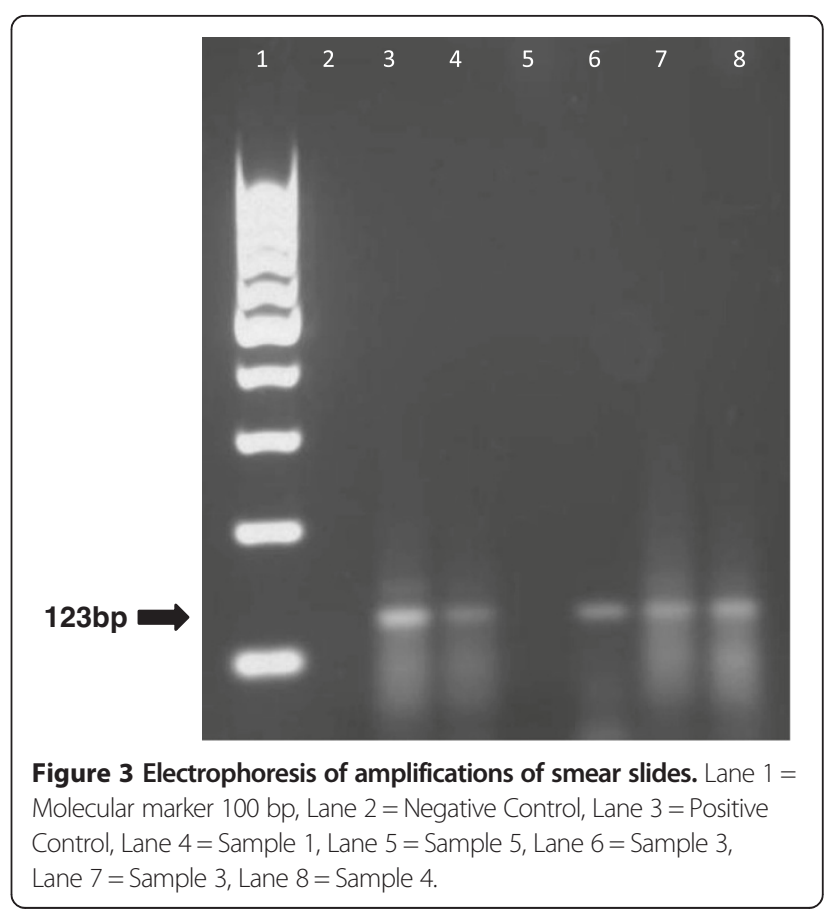


detergent with high capacity for breaking lipid-protein interactions, performing so the cells lysis and facilitating DNA release from them; which results in good extraction and reduces the presence of PCR inhibitors. In addition, it is a single stage extraction method, eliminating so the DNA loss that occurs when using multiple stages.

This is a preliminary study with low number of samples; however, as molecular tests are very expensive in developing countries and, therefore, not routinely required as diagnostic tools by physicians, the implantation of these protocols in such countries could be a valid alternative to investigate TB; in addition, the cases included in this study are suspected of having TB and, effectively, they proceed from a high complexity hospital of the public health system.

The limitation of smear slides requires the use of a large panel in the study, to confirm sensitivity and specificity values; so, Extraction Protocol 3 would be ideal for laboratories where only bacilloscopy is performed, as is the case of several locations in Brazil. Additionally, it would eliminate the 'biosafety issue' during transportation of slides to molecular biology labs. The relevance of amplifying DNA extracted directly from smear slides is because bacilloscopy does not differentiate bacterial species, while IS6110 sequence amplification allows a rapid identification of these mycobacteria, as it is a specific sequence of MTC, distinguishing them from MNT. Therefore, new "in house" extraction methods should be standardized and tested, as shown in this study.

\section{Conclusion}

The results of this work lead to conclusion that Chelex + NP-40 method (Extraction Protocol 3) for M. tuberculosis DNA extraction from cultures and slides, is able to provide a good quantity of interference free DNA, mainly in samples with low concentrations of genetic material; which justifies its use in the molecular diagnosis of TB.

\section{Abbreviations \\ M. tuberculosis: Mycobacterium tuberculosis; TB: Tuberculosis; \\ MTC: Mycobacterium tuberculosis complex; PCR: Polimerase chain reaction.}

\section{Competing interests}

The authors declare no competing interests.

\section{Authors' contributions}

SSM, WSC and INA planned and designed the experiments. INA performed the experiments. SSM, WSC and INA analyzed the data. SSM, WSC, INA, MLR and ERDC wrote the paper. All authors read and approved the final manuscript.

\section{Acknowledgements}

The Minas Gerais Research Foundation (FAPEMIG) and the Graduate department of the Medicine Faculty, Federal University of Minas Gerais for the financial support. To the collaborators: Lúcia Tavares Paradizi, Ana Lethícia Figueiredo and Lida Jouca, and all integrated laboratories employees.

\section{Author details}

${ }^{1}$ Federal University of Minas Gerais, Belo Horizonte, Brazil. ${ }^{2}$ State Foundation for Production and Research in Health (FEPPS), Porto Alegre, Brazil. ${ }^{3}$ Research Group Coordinator FM/UFMG_REDE-TB, Belo Horizonte, Minas Gerais, Brazil.

Received: 30 May 2013 Accepted: 16 December 2013

Published: 28 December 2013

\section{References}

1. Amim I, Idrees M, Awan Z, Shashid M, Afzal S, Hussain A: PCR could be a method of choice for identification of both pulmonary and extrapulmonary tuberculosis. BMC Research Notes 2011, 4:332.

2. Van Der Zandem AGM, Te Koppele Vije EM, Vijay Bhanu N, Van Soolingen D, Schouls LM: Use of DNA Extracts from Ziehl Neelsen Stained Slides for Molecular Detection of Rifampin Resistence and Spoligotyping of Mycobacterium tuberculosis. J Clin Microbio/ 2003, 41(3):1101-1108.

3. Haldar S, Chakravorty S, Bhalla M, Majumdar DS, Tyagi SJ: Simplified detection of Mycobacterium tuberculosis in sputum using smear microscopy and PCR with molecular beacons. J Med Microbiol 2007, 56(10):1356-1362.

4. Kolk AHJ, Noordhoek GT, De Leeuw O, Van Emden JDA: Mycobacterium smegmatis strain for detection of Mycobacterium tuberculosis by PCR used as internal control for inhibition of amplification and for quantification of bacteria. J Clin Microbiol 1994, 32(5):1354-1356.

5. Barani R, Saranga G, Antony T, Periyasami S, Kindo AJ, Srikanth P: Improved detection of Mycobacterium tuberculosis using two independent PCR targets in a tertiary care centre in South India. J Infect Dev Ctries 2012, 6(1):46-52

6. Nagdev KJ, Kashyap RS, Deshpande PS, Purohit HJ, Taori GM, Daginawala HF: Determination of polymerase chain reaction efficiency for diagnosis of tuberculous meningitis in Chelex-100 $0^{\circ}$ extracted DNA samples. Int J Tuberc Lung Dis 2010, 14(8):1032-1038.

7. Suresh N, Arora J, Pant H, Rana T, Singh UB: Spoligotyping of Mycobacterium tuberculosis DNA from Archival Ziehl-Neelsen-stained sputum smears. J Microbiol Methods 2007, 68(2):291-295.

8. Van Der Zanden AGM, Hoeilmann FGC, Weltevred EF, Schouls LM, Van Embden JDA: Simultaneous detection and strains differentiation of Mycobacterium tuberculosis complex in paraffin wax embedded tissues and stained microscopic preparation. J Clin Pathol 1998, 51(4):209-214.

9. da Saúde M: Manual Nacional de Vigilância Laboratorial da tuberculose e outras Micobactérias. Brasília: Ministério da Saúde; 2009.

10. Otal I, Martin C, Frebault LW, Thierry D, Gicquel B: Restriction fragment length polymorphism analysis using IS6110 as an epidemiological marker in tuberculosis. J Clin Microbiol 1991, 29(6):1252-1254.

11. Elbir H, Mushin A, Babiker A: Short report: a one-step DNA PCR-based method for the detection of Mycobacterium tuberculosis complex grown on Lowenstein-Jensen media. Am J Trop Med Hyg 2008, 78(2):316-317.

12. Al-Mutairi NM, Ahmad S, Mokkadas E: Performance comparison of four methods for detecting multidrug-resistant Mycobacterium tuberculosis strains. Int J Tuberc Lung Dis 2011, 15(1):110-115.

13. Leao SC, Martin A, Mejia GI, Palomino JC, Robledo J, Telles MAS, Portaels F: Pratical handbook for the phenotypic and genotypic identification of mycobacteria. Section II - Methodological Procedures 2004, 115-116. Printed by Vanden B. Brugues.

14. Sambroock J, Fritsch EF, Maniats T: Molecular Cloning - a laboratory manual on the web. Chapter 8. In Vitro Amplification of DNA by the Polymerase Chain Reaction. Edited by Cold Spring Harbor Laboratory Press. USA; 2001:696.

15. Sambroock J, Russell DW: Spectrophotometry of DNA or RNA. Molecular Cloning 2001, A8:20-21. Third edition.

16. Mesquita RA, Anzai EK, Oliveira RN, Nunes FD: Avaliação de três métodos de extraction de DNA de material parafinado para amplificação de DNA genômico pela técnica da PCR. Pesqui Odonto Bras 2001, 15(4):314-319.

17. Barea JA, Pardini MIMC, Gushiken T: Methodos of DNA extraction from archived materials and rare sources for utilization in polymer reaction. Rev bras Hematol Hemoter 2004, 26(4):274-281.

18. Telenti A, Marchesi F, Balz M, Bally F, Bottger EC, Bodmer T: Fast identification of mycobacteria to species level by polymerase chain reaction and restriction enzyme analysis. J Clin Microbiol 1993, 31(2):175-178.

doi:10.1186/1756-0500-6-561

Cite this article as: de Almeida et al:: Evaluation of six different DNA extraction methods for detection of Mycobacterium tuberculosis by means of PCR-IS6110: preliminary study. BMC Research Notes 2013 6:561. 